\title{
PEMANFAATAN GULA MERAH DAN AIR KELAPA TERHADAP PERTUMBUHAN AYAM BROILER
}

\author{
THE USAGE OF PALM SUGAR AND COCONUT WATER ON THE GROWTH OF \\ BROILER
}

Lily joris ${ }^{1)}$ dan S Fredriksz ${ }^{2)}$

Dosen Jurusan Peternakan Fakultas Pertanian Universitas Pattimura

Joris.lily@gmail.com/shirleyfredrisz90@gmail.com

\begin{tabular}{|l|l}
\hline Diterima: 10 Maret 2019 & Disetujui: 24 Maret 2019
\end{tabular}

\begin{abstract}
Abstrak
Tujuan penelitian ini untuk mengetahui pengaruh pemanfaatan air kelapa dan gula merah dalam air minum terhadap pertumbuhan ayam broiler. Hasil penelitian dapat menjadi informasi bagi peternak dan pengguna lainnya dalam memanfaatkan air kelapa dan gula merah untuk meningkatkan pertumbuhan ayam broiler. Penelitian ini merupakan penelitian eksperimen menggunakan Rancangan Acak Lengkap (RAL) dengan 3 perlakuan dan 5 ulangan yaitu Perlakuan $\mathrm{P} 0=$ pakan + air minum biasa $($ kontrol); P1 $=$ Pakan + minuman air kelapa; P2 = Pakan + minuman air gula merah. Variabel yang diamati adalah : konsumsi air, konsumsi pakan, pertambahan bobot badan dan konversi pakan. Hasil penelitian menunjukan bahwa konsumsi air berbeda nyata, konsumsi pakan tidak berbeda nyata, PBB berbeda nyata, konversi pakan berbeda nyata. Hasil penelitian pemanfaatan air kelapa dan gula merah $1 \%$ dalam air minum bagi ternak ayam broiler memberikan hasil yang baik, meskipun belum berpengaruh terhadap jumlah ransum yang dikonsumsi dan konversi ransum. Dari hasilpenelitian ini disarankan untuk meningkatkan bobot badan ayam broiler sebaiknya digunakan gula merah sebanyak $1 \%$ dalam air minum.
\end{abstract}

Kata kunci: gula merah, air kelapa dan pertumbuhan ayam broiler.

\begin{abstract}
The purpose of this research is to find out the effect of using coconut water and palm sugar in drinking water to the growth of broiler. The result of this research could be used as information for the farmers and other users in utilizing coconut water and brown sugar increasing the growth of broiler. This research is an experiment that uses a Complete Random Design with 3 treatments and 5 repetitions which are treatments $\mathrm{P} 0=$ Feed + Regular water (Controlled); $\mathrm{P} 1=$ Feed + Coconut Water; P2 $=$ Feed + Palm Sugar Water. The variables that are observed are: water consumptions, feed consumptions, weight gain and food conversion. Research result shows that water consumption has an apparent difference, feed consumption has no apparent difference, weight gain shows an apparent difference, and food convection shows apparent difference. Research.result shows that utilizing $1 \%$ coconut water and brown sugar for broiler has a good result, despite has not yet shows any effects on the amounts of consumed ration or the ration convection. Based on this research it is suggested, to increase the growth and weight of broiler utilize $1 \%$ of brown sugar in the chicken's drinking water.
\end{abstract}

Keywords: palm sugar, coconut water and growth of broiler 
PENDAHULUAN

Meningkatnya

permintaan

dagingayam untuk konsumsi sebagai dampak dari kebutuhan meningkatnya daya beli masyarakat dan kebutuhan protein berharga murah menyebabkan perlu ditingkatkannnya produktivitas peternakan ayam khususnya ayam pedaging. Data BPS menunjukan bahwa harga protein per gram daging ayam sebesar Rp.168,39 dengan komposisi protein 182 gram per kilogram lebih murah dibandingkan harga protein daging sapi sebesar Rp.612,6 per gram dan protein daging kambing sebesar Rp. 673,41 per gram. Konsumsi daging ayam ras masyarakat Indonesia tahun 2017 sebesar $5,68 \mathrm{~kg} / \mathrm{kap} /$ tahun meningkat 573 gram ( $11.2 \%)$ dari tahun sebelumnya. Dengan makin menjamurnya kuliner berbasis daging ayam dari warung pinggir jalan sampai pusat perbelanjaan membuat konsumsi daging ayam mengalami kenaikan sepanjang tahun 2013 sampai tahun 2017.

Kebutuhan protein hewani di Indonesia saat ini sangat tinggi, seiring dengan meningkatnya jumlah penduduk serta kesadaran masyarakat bahwa protein hewani diperlukan dalam memenuhi kebutuhan gizi. Protein hewani menjadi sangat penting karena mengandung asamasam amino yang mendekati susunan asam amino yang dibutuhkan manusia sehingga akan lebih mudah dicerna dan lebih efisien pemanfaatannya (Bahri et al., 2005). Komoditas peternakan sumber protein hewani yang dapat diandalkan salah satunya adalah ternak unggas terutama ayam.

Tingginya permintaan daging ayam termasuk peruntukan untuk eksport seperti ke jepang, Saudi Arabia, hongkong, PNG sebesar 118,81 ton pada tahun 2016-2018 menyebabkan perlu ditingkatkannya produksi ayam pedaging (Waluyo, 2018).

Berbagai upaya dilakukan peternak untuk meningkatkan produksi ayam pedaging seperti modifikasi system pemeliharan, perbaikan kualitas pakan sampai pemberian berbagai feed additive. Hal ini disebabkan karena semakin cepat laju pertumbuhan ayam semakin banyak ransum atau pakan yang dikonsumsi yang berpengaruh pada besarnya biaya yang dikeluarkan untuk menyediakan pakan.Untuk mencapai produktivitas ayam yang optimaldiperlukan berbagai upaya dalampemeliharaan yang dimulai sejak telur ditetaskan sampai fase finisher. Pada saat anak ayam (DOC) tiba ditempat tujuan perlu diberikan air gula untuk mengurangi stress karena transportasi. Air gula juga dapat diberikan pada ayam dengan berbagai umur pertumbuhan jika kondisi stess karena cekaman suhu, lingkungan dan vaksinasi.

Pertumbuhan yang optimal dapat diperoleh dengan pemberian pakan yang sesuai dengan kebutuhan ternak baik 
kuantitas maupun kualitas.Kualitas pakan berupa kesesuaian dan ketersediaan zat gizi.Kebutuhan zat gizi ayam pedaging bergantung pada umur pertumbuhan dimana pada umur pertumbuhan awal atau fase starter ( 0 - 3 minggu) membutuhkan protein lebih tinggi untuk pertumbuhan sedangkan pada fase grower sampai finisher (4 minggu- panen) membutuhkan energy yang lebih tinggi untuk pembentukan jaringan otot dan daging. Pakan dengan kandungan energy yang tinggi dapat dikurangi biayanya dengan memerikan atau menambahkan bahan pakan yang lebih murah sepertiair gula merah dan air kelapa yang merupakan limbah dari produk kelapa( Karnosuhardjo 1981)menyatakan bahwa hasil analisa gula merah terdiri dari $66,187 \%$ sukrosa, $11,69 \%$ air, $5,99 \%$ gula pereduksi dan $15,37 \%$ zat buka gula yang larut dalam air, sementara air kelapa mengandung 7,27\% gula atau 3 gram per $100 \mathrm{ml}$ air kelapa(Warisno,2004). Hasil analisis ini menunjukkan bahwa gula merah dan air kelapa dapat dimanfaatkan sebagai bahan sumber energy dalam upaya peningkatan produktivitas ayam pedaging.

\section{Tujuan Penelitian dan Manfaat Penelitian}

- Penelitian ini bertujuan mengetahui pengaruh yang dihasilkan dari pemanfaatan air kelapa dan gula merah dalam air minum terhadap pertumbuhan ayam broiler.
- Diharapkan hasil penelitian ini dapat menjadi sumber informasi bagi peternak dan pengguna lainnya dalam memanfaatkan air kelapa dan gula merah untuk meningkatkan pertumbuhan ayam broiler.

\section{METODE PENELITIAN}

1. Waktu dan Tempat

Penelitian ini dilakukan pada bulan juni-juli 2017 di unit perkandangan Jurusan Peternakan Fakultas Pertanian Unpatti.

2. Bahan dan Alat

Dalam penelitian ini digunakan 90 ekor ayam broiler (DOC) umur 1 hari dengan berat awal \pm 37 gram.Pakan yang digunakan pakan komersial BR I produk PT Panca Patriot Prima Sidoarjo. Air minum yang digunakan adalah air biasa, air kelapa tua dan air gula merah. Air gula merah merupakan campuran $1 \%$ gulamerah dalamair minum yang diberikan sesuai kebutuhan ternak. Gula merah yang digunakan berbentuk segiempat dibungkus daun jati hijau ( di Ambon dikenal dengan sebutan gula makasar). Sumber air kelapa berasal dari pengumpulan di pasar Rumah Tiga dan diberikan sesuai dengan kebutuhan ternak.Air kelapa diperoleh dari pengumpulan dipasar rumah tiga setiap pagi dan sore hari.

Alat yang digunakan dalam penelitian ini adalah : kandang 15 petak ukuran $100 \times 100 \mathrm{~cm}$, dilengkapi tempat makan dan air minum. Gelas ukur, 
Timbangan untuk menimbang ternak dan pakan. Peralatan lain adalah sekop, sapu kertas label, kantong plastic, loyang dan ember serta alat tulis menulis.

Desain dan Prosedur penelitian

Penelitian ini merupakan penelitian eksperimen menggunakan Rancangan Acak Lengkap (RAL) dengan 3 perlakuan dan 5 ulangan yaitu Perlakuan $\mathrm{P} 0=$ pakan + air minum biasa ( kontrol); P1 = Pakan + minuman air kelapa; P2 = Pakan + minuman air gula merah. Variabel yang diamati dalam penelitian ini adalah : konsumsi air, konsumsi pakan, pertambahan bobot badan dan konversi pakan. Pengambilan data konsumsi pakan diambil setiap hari dengan menghitung selisih antara ransum yang diberikan dengan sisa pada keesokan harinya. Pertambahan bobot badan didapat dengan menimbang ternak pada setiap minggu.Konversi pakan merupakan merupakan perbandingan atara pertambahan bobotbadan dan konsumsi pakan.

Analisis data menggunakan model matematika sesuai petunjuk Gaspersz (1995) sebagai berikut :

$$
Y \mathbf{i j}=\mu+\tau+\varepsilon_{i j}
$$

dimana : Yij = konsmsipakan, pertambahan boot badan dan konversi pakan $\mathrm{i}=1,2,3 ; \mathrm{j}=1,2,3,4,5$

$\mu=$ nilai rataan umum

$\tau=$ pengaruh pemberian air kelapa atau gula merah ke $\mathrm{i}$

$\boldsymbol{\varepsilon}_{\mathrm{ij}}=$ galat percobaan

Jika hasil penelitian menunjukan ada perbedaan nyata antar perlakuan akan dilanjutkan dengan menggunakan uji beda nyata terkecil (BNT)

\section{HASIL DAN PEMBAHASAN}

Data hasil penelitian dapat dilihat pada tabel.1.

Tabel 1. Rata-rata KonsumsiAir Minum, Pakan, Konversi Pakan dan Pertambahan Bobot Badan Selama 35 Hari Penelitian.

\begin{tabular}{|c|l|l|l|l|}
\hline $\begin{array}{c}\text { Perlak } \\
\text { uan }\end{array}$ & $\begin{array}{l}\text { Konsumsi } \\
\text { Air } \\
\text { Minum } \\
(\mathrm{ml})\end{array}$ & $\begin{array}{l}\text { Konsums } \\
\text { i Pakan } \\
\text { (gr) }\end{array}$ & $\begin{array}{l}\text { Pertamba } \\
\text { han } \\
\text { Bobot } \\
\text { Badan } \\
\text { (gr) }\end{array}$ & $\begin{array}{l}\text { Konver } \\
\text { si } \\
\text { Pakan }\end{array}$ \\
\hline P0 & $9118.8^{\mathrm{b}}$ & $1805.69^{\mathrm{a}}$ & $1619.40^{\mathrm{b}}$ & $0.89^{\mathrm{a}}$ \\
\hline P1 & $10287.2^{\mathrm{a}}$ & $1799.14^{\mathrm{a}}$ & $1767.63^{\mathrm{a}}$ & $0.98^{\mathrm{b}}$ \\
\hline P2 & $9081.8^{\mathrm{b}}$ & $1806.66^{\mathrm{a}}$ & $3046.20^{\mathrm{a}}$ & $1.69^{\mathrm{c}}$ \\
\hline
\end{tabular}

Superscib yang berbeda pada kolom yang sama menunjukan adanya perbedaan antar perlakuan

\section{Konsumsi Air.}

Air merupakan zat yang sangat penting bagi unggas, karena sekitar 60 persen dari bobot ayam berupa cairan. Secara fisiologis, air berperan untuk keberlangsungan proses biologis dan kimiawi dalam tubuh, oleh karena itu penyediaan air untuk ayam di kandang, menjadi titik sentral bagi kesuksesan manajemen budi daya ayam, baik untuk petelur maupun pedaging disebabkan pakan komersial unggas yang beredar di 
pasaran saat ini hanya mengandung kadar air sebesar 10\%. Hal ini menunjukan bahwa air minum bagi ayam sangatlah penting.

Konsumsi air pada pada penelitian ini berkisar antara 9081.8 - $10287.2 \mathrm{ml} / 35$ hari untuk perlakuan control (9118.8 ml), penambahan gula merah $(9081.8 \mathrm{ml})$ dan air kelapa (1027.2). Konsumsi air perlauan P0 (kontrol) dan penambahan gula merah ( P3) masih berada dibawah konsumsi air yang direkomendasikan untuk ternak ayam broiler umur 5 minggu (30-36 hari) sebesar $9310 \mathrm{ml} / 35$ hari (Alex S., 2015).

Hasil penelitian menunjukan bahwa konsumsi air dalam perlakuan ini berbeda nyata antara konsumsi air minum biasa (kontrol) , air kelapa maupun air gula merah. Hasil analisis statistik memperlihatkan ada perbedaan yang signifikan antara pemberian air kelapa dibandingkan air minum biasa maupun air gula merah. Tingginya konsumsi airkelapa diduga disebabkan karenadalam air kelapa terkandungbanyak komponen mineral seperti biotin, phosphor, kalium magnesium,natrium dan calcium ( Direktorat Gizi Depkes RI 1979).RBarlina (2004) menganalisa terdapat sekitar 11 macam mineral dalam air kelapa.Ransum dengan kadar protein dan kadar garam tinggi serta kandungan karbohidrat yang rendah mengakibatkan turunnya volume urine, karena metabolisme ransum tersebut menghasilkan produk akhir berupa urea, natrium dan badan- badan keton dengan konsentrasi tinggi sehingga perlu peningkatan konsumsi air untuk menurunkan konsentrasi produk yang terbentuk. (Pilliang dan Soewondo.,1991). Makin besar zat- zat mineral danprotein dalam ransum, makin besar pula jumlah air yang hilang dan sesuai dengan itu akan mempertinggi kebutuhan air. Konsumsi air yang tinggi berpengaruh pada konsumsi pakan. (Anggorodi,1990). Selanjutnya Kusnadi (2006) mengatakan bahwa Ayam broiler termasuk hewan homeothermis, akan mempertahankan suhu tubuhnya dalam keadaan relatif konstan antara lain melalui peningkatan frekuensi pernafasan dan jumlah konsumsi air minum serta penurunan konsumsi ransum.

\section{Konsumsi Pakan}

Pakan yang diberikan pada ternak harus mengandung nutrisi yang dibutuhkan sehingga pertambahan bobot badan sebagai indikator pertumbuhan yang dapat diukur bisa terlihat dengan jelas.

Hasil penelitian memperlihatkan tidak terdapat perbedaan konsumsi pakan dari ketiga perlakuan yang diberikan.Konsumsi pakan berkisar antara 1799.14 gr (P1); 1805.69 (P0) dan (P2) 1806.66 gram/ekor /35 hari. Besaran pakan yang dikonsumsi ini lebih besar dari yang direkomendasikan Alex, (2015), sebesar $111 \mathrm{gr} / \mathrm{e} / 35$ hari, tetapi lebih rendah dari yang direkomendasi Kusnadi (2006) 
sebesar 1918 gr/e/ untuk 5 minggu. Tinggi rendahnya konsumsi ransum ternak dipengaruhi oleh kandungan energy ransum, besar dan bangsa ayam serta tempratur lingkungan.Kandungan energy dari ransumyang diberikan berkisar antara 2820-2920 Kkal/kg lebih rendah dari standar yang dikemukakan oleh Rasyaf (2004) sebesar 2900-3200 Kkal/kg ransum.Sumber energy bagi ternak ayam dalam penelitian ini berasal dari pakan dan air minum yang dikonsumsi.Meskipun demikian konsumsi pakan yang tidak berbeda menunjukan bahwa energy yang tersedia dalam ransum yang dikonsumsi telah cukup atau sesuai dengan kebutuhan ternak.Hal ini menunjukan bahwa penggunan air kelapa dan air gulamerah belum memberi pengaruh pada penggunaan ransum yang diberikan. Rizal (2006) menyatakan bahwa angka kebutuhan energy yang absolut tidak ada karena ayam dapat menyesuaikan jumlah ransumyang dikonsumsi dengan kebutuhan energy tubuhnya. Kartasudjana dan Supriatna (2006) Menyatakan bahwa Ayam mengkonsumsi ransum untuk memenuhi kebutuhan energinya, sebelum kebutuhan energy terpenuhi ayam akan terus makan. Jika ayam diberi makanan dengan kandungan energi rendah maka ayam akan makan lebih banyak. Sebaliknya jika kandungan energy tinggi ayam akan makan lebih sedikit.
Air gula merah bukanlah merupakan sumber energy utama, jadi pemberian larutan gula merah sifatnya hanyalah sebagai nutrisi tambahan, sedangkan untuk sumber energy utama tetaplah menggunakan ransum yang tepat agar mendapatkan hasil yang terbaik ( Pratama,2018). Hasil penelitian Sipahutar (2018) menunjukan bahwa nira aren tidak mampu meningkatkan daya konsumsi ayam broiler,namun dengan pemberian nira aren tingkat konsumsi pakanakan lebih rendah dan laju pertambahan bobot badan lebih cepat. Diasumsikan bahwa nira aren dalam air minum mampu melengkapi kandungan yang ada didalam pakan.Daya konsumsipakan yang rendah disebabkan ayam lebih merasa cepat kenyang karena kandungan karbohidrat yang ada pada nira aren telahmampu memenuhi kebutuhan metabolisnya.

\section{Pertambahan Bobot Badan}

Salah satu kriteria untuk mengukur pertumbuhan adalah dengan mengukur pertambahan bobot badan (PBB), hal ini diartikan sebagai kemampuan untuk mengubah zat-zat nutrisi yang ada dalam ransum menjadi daging (Tillman et al., 1998). Selanjutnya dikatakan bahwa Pertambahan bobot badan merupakan kenaikan bobot badan yang dicapai oleh seekor ternak selama periode tertentu. Ayam broiler merupakan ayam yang memiliki ciri khas tingkat pertumbuhan 
yang cepat sehingga dapat dipasarkan dalam waktu singkat.Pertambahan bobot badan diperoleh dengan pengukuran kenaikan bobot badan melalui penimbangan berulang dalam waktu tertentu misalnya tiap hari, tiap minggu, tiap bulan, atau tiap tahun (Tillman et al., 1998). Ayam broiler mampu membentuk $1 \mathrm{~kg}$ daging dalam waktu 30 hari, dan 1,5 kg dalam waktu 40 hari. Biasanya ayam dipanen setelah umur mencapai 45 hari dengan bobot berkisar 1,5 $-2,5 \mathrm{Kg}$ (Didinkaem,2006).

Hasil penelitian menunjukkan bahwa rata rata bobot badan ayam selama penelitian berkisar antara $1619.40(\mathrm{P} 0), 1767.63(\mathrm{P} 1)$ dan (P3) sebesar 3046. 20 gram/e/5 minggu. Berat ini lebih besar dibandingakan hasil rekomendasi Alex (2015) sebesar 1,8 - $2 \mathrm{~kg} / \mathrm{e} / 5$ minggu atau rekomendasi Charoem Pokphan (2011) sebesar 2049 gr/e/5 minggu. Hasil analisa statistik menunjukkan bahwa ada perbedaan berat ayam antar perlakuan yang dicobakan dimana perlakuan pemberian gulamerah (P3) dan air kelapa (P2) berbeda terhadap kontrol (P1). Tingginya pertambahan bobot badan pada perlakuan pemberian air kelapa dan gula merah disebabkan karena zat gizi yang dibutuhkan dalam hal ini energy yang penting untuk pertumbuhan yang ditandai dengan peningkatan bobot badan berasal dari pakan dan air minum yang dikonsumsi.Menurut Karnosuharjo (1981), gula merah mengandung $66.187 \%$ sukrosa yang merupa bagian dari karbohidrat yang fungsi utamanya sebagai penghasil energi.Tujuan pemberian gula merah adalah untuk menambah sumber nutrisi/sumber energi melalui air minum agar mudah diserap dan stamina ayam dapat meningkat. Barlina (2004) menemukan bahwa dalam satu butir air kelapa terkandung $4 \%$ karbohidrat dengan 17.4 Kkal energy. Hal ini berpengaruh pada sumbangan energy dalam air minum yang berpengaruh terhadap pertambahan bobot badan ayam. Hasil penelitian dari Aryanti dkk (2013) menunjukan bahwa, Bila dibandingkan dengan berat badan standar untuk ayam kampung pedaging, pada kelompok yang mendapatkan perlakuan air gula merah $1 \%$ di air minum untuk setiap minggunya selalu memenuhi kisaran berat badan yang diharapkan, bahkan kadangkadang ditemukan melebihi dari batas maksimal yang diharapkan. Pertambahan bobot badan yang tinggi pada perlakuan ayam yang diberi gula merah juga disebabkan karena pemberian gula merah dapat mengurangi Stres dan memperbaiki performans ayam (Nanggoy, 2012).

\section{Konversi Pakan}

Konversi pakan atau Feed Converstion Ratio (FCR) merupakan perbandingan antara jumlah ransum yang dikonsumsi dengan pertamabahan bobot badan. Nilai konversi pakan dipengaruhi oleh beberapa faktor antara lain genetik, tipe pakan yang digunakan, feed additive 
yang digunakan dalam pakan, manajemen pemeliharaan, dan suhu lingkungan (James, 2004). Jumlah pakan yang digunakan mempengaruhi perhitungan konversi ransum atau Feed Converstion Ratio (FCR).Angka konversi ransum yang kecil berarti jumlah ransum yang digunakan untuk menghasilkan satu kilogram daging semakin sedikit (Edjeng dan Kartasudjana, 2006).Semakin tinggi konversi ransum berarti semakin boros ransum yang digunakan.

Hasil penelitian menunjukan bahwa angka konversi ransum dalampenelitian ini masing - masing $(\mathrm{P} 0)=0,089 ;(\mathrm{P} 1)=0,98$ dan $(\mathrm{P} 2)=1,72$. Hasil analisis statistik menunujukan bahwa perlakuan P0 , P1dan P2 berbeda satu dengan lainnya.Nilai konversi ransum perlakuan P1 memperlihatkan bahwa banyak ransum yang dikonsumsi tidak memberikan pengaruh positif terhadap pertambahan bobot badan. Hal ini disebabkan karena konsumsi air yang tinggi (air kelapa) disertai dengan masuknya berbagai komponen mineralyang terkandung didalamnya yang berpengaruh pada nilai FCR. faktor utama yang mempengaruhi konversi pakan adalah tempratur, kulitas pakan, jenis pakan, kualitas air, penyakit dan manajemen pemeliharaan, selain itu meliputi faktor penerangan, pemberian pakan, dan faktor social (Anggorodi, 1990). Tingginya nilai konversi ransum pada perlakuan P2 sejalan dengan besarnya peningkatan berat badan yang dihasilkan.Semakin besar dan tua maka nilai konversinya semakin tinggi.Konversi pakan ayam broiler strain CP 707 yang dipelihara pada suhu nyaman pada umur lima minggu adalah 1,62. Nilai konversi dalam penelitian ini lebih tinggi karena sumber energy untuk pertambahan bobot badan bukan hanya berasal dari pakan tetapi juga dari air gula merah yang dikonsumsi. Hasil penelitian dari Septiani dkk (2016) menghasilkan nilai rerata konversi pakan pada ayam pedaging sebesar 1,60 - 1,72. Tingginya hasil penelitian ini dipengaruhi oleh bobot karkas. Bobot karkas ayam ayam pedaging ditunjang oleh bobot hidup akhir yang tinggi pula.

\section{KESIMPULAN DAN SARAN}

\section{Kesimpulan}

- Hasil penelitian menunjukan bahwa perlakuan pemanfaatan air kelapa dan gula merah $1 \%$ dalam air minum bagi ternak ayam broiler memberikan hasil yang baik yang ditandai dengan tingginya bobot badan yang dihasilkan,meskipun demikian belum berpengaruh terhadap jumlah ransum yang dikonsumsi dan konversi ransum.

- Dari hasilpenelitian ini disarankan untukmeningkatkan bobot badan ayam broiler sebaiknya digunakan gula merah sebanyak $1 \%$ dalam air minum. 


\section{DAFTAR PUSTAKA}

Alex S., 2015. Jurus Sukses Beternak Ayam Pedaging. Penerbit pustaka Baru Press. Yogyakarta

Anggorodi, R., 1990. Ilmu Makanan Ternak Umum. Gramedia. Jakarta.

Aryanti F., Muhamad Bayu Dan Aji Nugroho B., 1993. Pengaruh Pemberian Air Gula Merah Terhadap Performans Ayam Kampung Pedaging.Jurnal Sains Veteriner.ISSN 0126-0426. Kandang Unggas Balai Besar Pelatihan Kesehatan Hewan Cinagara. Bogor.

Bahri, S., E. Masbulan, dan A. Kusumaningsih. 2005., Proses praproduksi sebagai faktor penting dalam menghasilkan produk ternak yang aman untuk manusia.http://www.pustaka deptan. go.id/publication/p3241054.pdf Diakses pada 10 Agustus 2018.

Barlina, R., 2004. Potensi buah kelapa muda untuk kesehatan dan pengolahannya.Jurnal Perspektif. Vol.3.No.2 .Balai Penelitian Kelapa Dan Palem Manado Sulawesi Utara.

Didinkaem 2006.Ayam broiler.http://www .Halalguide.info/conten/view/574/3 8/. (2 Februari 2012).

Direktorat Gizi Depkes RI 1979.Daftar komposisi bahan makanan. Bhatara Karya Akasara. Jakarta .

Gaspersz V., 1995. Teknik analisis dalam penelitian percobaan. Penerbit Tarsito Bandung.

James, R. G. 2004. Modern livestock and Poultry Production.7th Edition. Thomson Delmar Learning Inc., FFA Activities, London
Karnosuhardjo, B.I.,1981. Pengaruh pemberian gula merah terhadap perfomas ayam pedaging.Karya Ilmiah Institut Pertanian Bogor.

Kartasudjana, $\mathrm{R}$ dan E. Supriyatna 2006.Manejemen Ternak Unggas. Penebar Swadaya. Jakarta.

Kusnadi, E. dan F. Rahim. 2006. Performa dan Kandungan Hormon Triiodotironin Plasma Ayam Broiler Akibat Pengaruh Cekaman Panas di Daerah Tropis.Media Peternakan, vol. 32. No.3 Desember 2009, hlm. 155-162ISSN 0126-0472Terakreditasi B SK Dikti No: 43/DIKTI/Kep /20aji.net /articles /2015/16101424247036.pdf08

Nangoy F.J., 2012. Kajian Penyusutan Berat Badan Dan Peningkatan Suhu Ayam Briler Terimplementasi Kurkuma Dan Gula Aren Akibat Lama Transportasi. IJAS Volume 2.No.3 Edisi Des 2012. Jurnal Universitas Padjadjaran. Bandung.

Pilliang G.W dan Djoyosoebagio S., 1991.Fisiologi Nutrisi volume 1.PAU.IPB. Bogor.

Pratama. W.2018. https://budidayaternak. /manfaat-gula-merah untuk ayam/Diposting pada 9 Juli 2018

Rasyaf, M.,2004. Beternak Ayampedaging. Penerbit PT Swadaya.Jakarta.

Rizal Y., 2006. Ilmu Nutrien Unggas Andalas University Press. Padang.

Septiani Anggitasari, Osfar Sjofjan, dan Irfan Hadji Djunaidi. Pengaruh Beberapa Jenis Pakan Komersial Terhadap Kinerja Produksi Kuantitatif Dan Kualitatif Ayam Pedaging. Buletin Peternakan Vol. 40 (3): 187-196, Oktober 2016 ISSN-0126-4400 E-ISSN-2407876X 
Sipahutar L.W. dan Khairani., 2018 Potensi

Suplementasi Nira Aren (Arenga

pinnata Merr.) Terhadap Performa

Ayam Broiler.jurnal peternakan

volume : $02 \mid$ no: $01 \mid$ tahun 2018 | e-issn. 2599-1736| 1

Tillman A.D.,H. Hartadi., R. Reksohadiprodjo., S. Prawiro kusumo., S. Lebdosoekojo., 1998. Ilmu Makanan Ternak Dasar. UGM Press. Yogyakarta.

Waluyo., 2018., $\quad \underline{\text { https://JPP.go }}$ id/ekonomi/pertanian 327132

Warisno. 2004. Mudah dan praktis membuat nata de coco.Media Pustaka Jakarta. 